\title{
Chemical enhancement of footwear impressions in blood on fabric - part 1: protein stains
}

Kevin J. Farrugia, Niamh NicDaéid, Kathleen A. Savage and Helen Bandey

This is the accepted manuscript (C) 2010, Elsevier

Licensed under the Creative Commons Attribution-NonCommercialNoDerivatives 4.0 International:

http://creativecommons.org/licenses/by-nc-nd/4.0/

\section{(c) EY-NC-ND}

The published article is available from doi:

http://dx.doi.org/10.1016/j.scijus.2010.11.001 


\title{
Chemical Enhancement of Footwear Impressions in Blood on Fabric - Part 1: Protein Stains
}

\author{
Kevin J. Farrugia ${ }^{a}$, Niamh NicDaéid ${ }^{a^{*}}$, Kathleen A. Savage ${ }^{a^{*}}$, Helen Bandey ${ }^{b}$ \\ ${ }^{\text {a }}$ Centre for Forensic Science, WestCHEM, Department of Pure and Applied Chemistry, \\ University of Strathclyde, Glasgow, G1 1XW, UK \\ ${ }^{\mathrm{b}}$ Home Office Scientific Development Branch, Fingerprint \& Footwear Forensic Group, \\ Woodcock Hill, Sandridge, St. Albans, AL4 9HQ, UK
}

\section{* CORRESPONDING AUTHORS}

Niamh Nic Daéid and Kathleen A. Savage

Centre for Forensic Science, WestCHEM, Department of Pure and Applied Chemistry,

University of Strathclyde, Glasgow, G1 1XW, UK

n.nicdaeid@strath.ac.uk

kathleen.savage@strath.ac.uk 


\begin{abstract}
A range of protein stains were utilised for the enhancement of footwear impressions on a variety of fabric types of different colours with blood as a contaminant. A semi-automated stamping device was used to deliver test impressions at a set force to minimise the variability between impressions; multiple impressions were produced and enhanced by each reagent to determine the repeatability of the enhancement. Results indicated that while most protein stains used in this study successfully enhanced bloody impressions on light coloured fabrics, background staining caused interference on natural fabrics. Enhancement on dark coloured fabrics was only achieved using fluorescent protein stains.

A further comparison was performed with commercially available protein staining solutions and solutions prepared within the laboratory from the appropriate chemicals. Both solutions seemed to perform equally well, though it is recommended to use freshly prepared solutions whenever possible.
\end{abstract}

Keywords: footwear impressions, blood, fabric, protein stain, 


\section{INTRODUCTION}

\section{Enhancement of marks on fabrics}

Commonly available textile materials have a wide compositional range that includes naturally occurring materials, such as wool and cotton, through to fully synthesised products such as nylon and polyester. The properties, such as porosity and surface morphology, of fabrics derived from these materials are highly variable and as a consequence fabric is considered to be a difficult and challenging surface for the chemical enhancement of marks such as fingerprints and footwear.

Previous reported research relating to the recovery and enhancement of impressions on fabric is limited to a few publications relating to experiences in casework. The enhancement of latent impressions has been reported with fabrics prepared from materials with a smooth finish and fine weave but it is also possible to successfully enhance marks on other types of fabric [1]. It has also been suggested that the chemical enhancement of marks on fabric may cause background staining [2], thus reducing the effectiveness of the methods, however, Zauner [1] suggested that this may not always be the case. Initial research in the early 1970s by the British Home Office for the recovery of latent fingerprints on paper and fabrics used radioactive sulfur dioxide gas [3] with limited success, and the enhanced impressions deteriorated over time. Spedding [4] however, suggested that the radioactive sulfur reacted with lipids in the fingerprint, making it potentially suitable for articles that had been immersed in water in a manner similar to physical developer [5-11] and oil red $\mathrm{O}$ techniques [12-18].

\section{Enhancement of marks in blood using protein specific stains}

The application of protein stains to bloody impressions is generally performed in a three-step process involving fixing, staining and de-staining.

\section{Fixing}

Fixing a bloody impression before protein staining is necessary to precipitate the basic proteins, so preventing leaching or diffusion of the blood. There are a range of mechanisms by which proteins can be fixed, such as cross-linking, dehydrating and precipitating [19]. Horobin [20] states that the 'commonest mechanistic factor for all fixatives is the disruption 
of the secondary and tertiary structure of proteins via change in the balance of lipophilic/hydrophilic regions'. Besides proteins, other molecules such as nucleic acids, lipids and polysaccharides can be involved in the fixation process [21]. This causes the solubility of the proteins in water to fall sharply, so preventing diffusion. Hussain and Pounds [22] demonstrated that fixing bloody impressions with 5-sulfosalicylic acid was safe, effective and convenient. 5-sulfosalicylic acid precipitates proteins present in blood by the formation of insoluble salts or complexes and by disruption of the protein structure [19, 23].

\section{Protein specific staining}

Biological stains and dyes have been widely used to impart colour to plant or animal tissues. Dyes can be described as coloured organic aromatic molecules with conjugated bonds and large systems of delocalised electrons providing visible colour and permit molecular binding to a material [19-20, 24-26]. In order to avoid ambiguity, dyes are described by a Colour Index (C.I.) number which is a five-digit number associated with each dye available in the market and has been developed by the Society of Dyers and Colourists (Bradford, UK) and the American Association of Textile Chemists and Colourists (Lowell, Massachusetts) [27].

Dyes can be separated into natural, acidic and basic groups. Natural dyes, such as haematoxylin, are directly extracted from animal or plant material. Acidic and basic dyes are in fact not acidic or basic in nature and their terminology relates to their usage for dyeing textiles under acidic or basic conditions [28-29]. Acidic dyes (example in figure 1) possess coloured anions in association with colourless cations whereas basic dyes possess coloured cations in association with colourless anions. Under acidic conditions, the protein is dyed by an acidic dye whereas under basic conditions the protein is dyed by a basic dye (figure 2). Stains prepared for application to proteins are often modified in order to facilitate the formation of appropriate charges of the anion and cation. For example, the United Kingdom Home Office Scientific Development Branch (HOSDB) [30] formulation of protein stains includes the addition of acetic acid to provide optimal conditions for acidic dyes. 


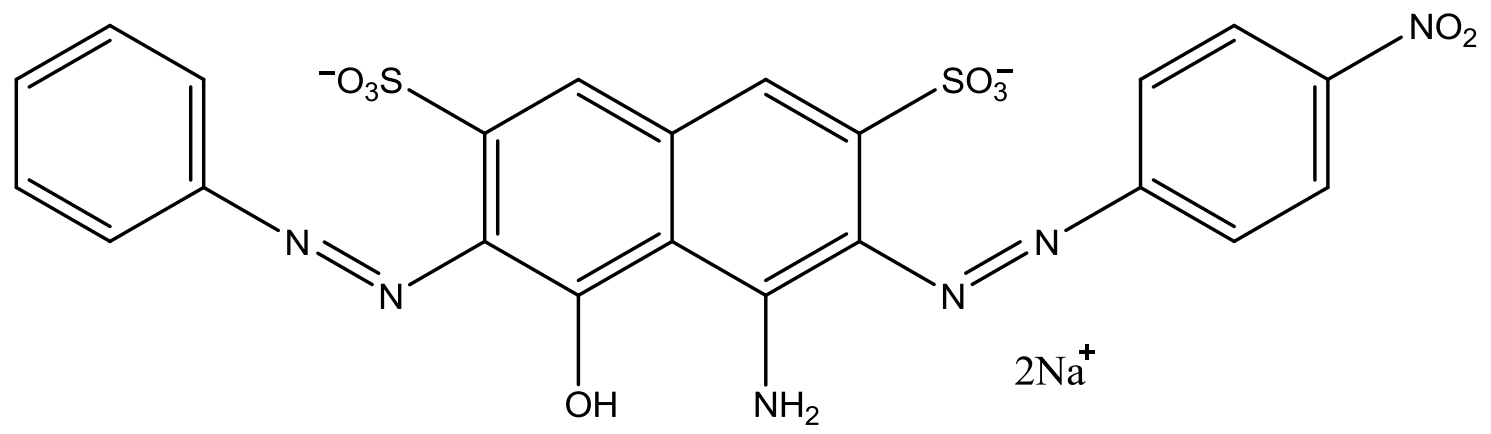

Figure 1 - Molecular Structure of Acid Black 1 (Acidic Dye)
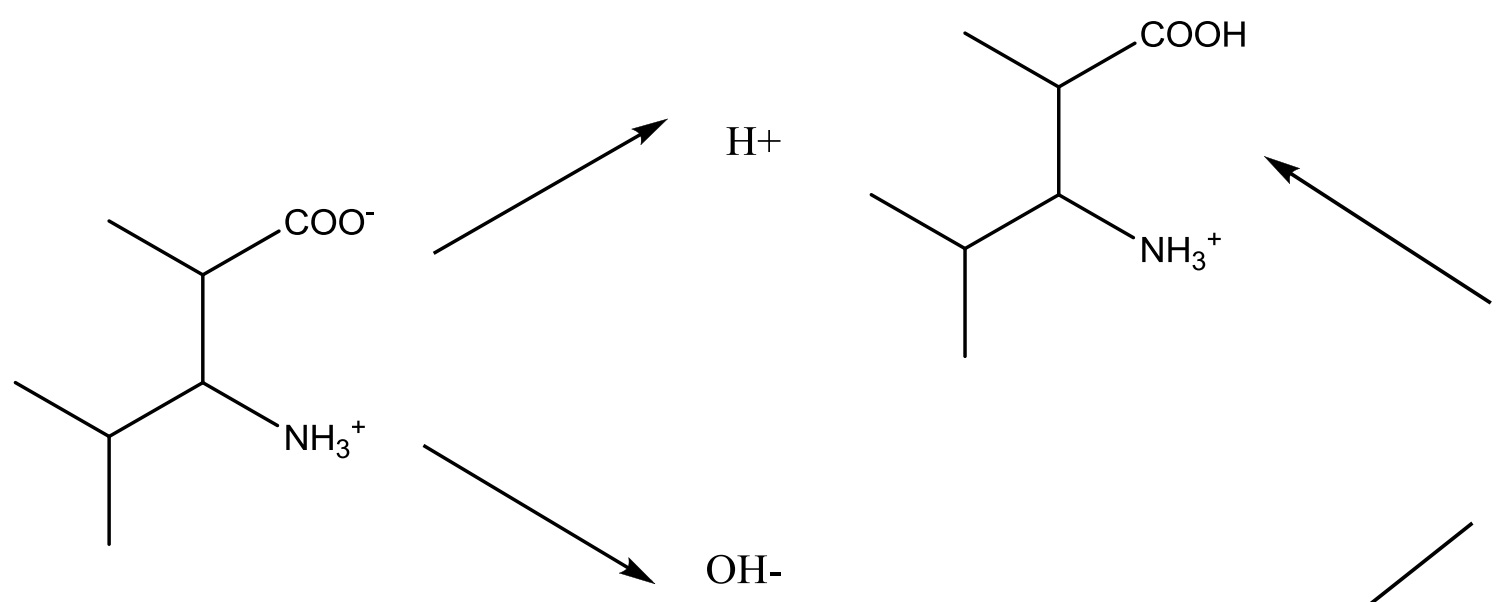

Protein

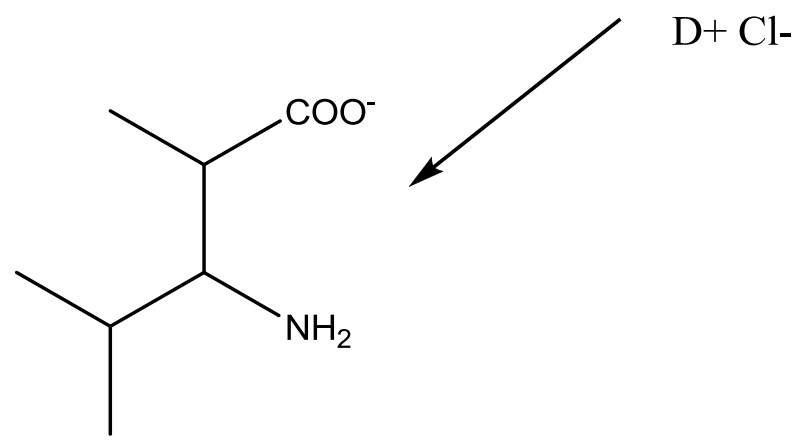

Figure 2 - Dye Reactions under different $\mathrm{pH}$ conditions 


\section{De-staining}

De-staining is a simple procedure used to remove the excess dye containing solution from the surface of interest. The material is either sprayed with or immersed in a de-staining solution and allowed to dry before examination either visually or under a variety of light sources.

\section{The use of protein stains for impressions in blood}

Protein stains will not detect constituents normally present in latent fingerprints but will react with amines or other groups within all proteins present in blood and other body fluids to yield a coloured complex [30-31]. In general, these chemicals are cheap, easy to apply and can be used for porous and non porous items. There are numerous protein stains available [32], however, the HOSDB [30] recommends using acid black 1 (AB1), acid violet 17 (AV17) and fluorescent acid yellow 7 (AY7). AB1 was also recommended on paper for the enhancement of footwear impressions in blood [33]. HOSDB [34] have recently suggested the use of a water/ethanol/acetic acid (WEAA) based $\mathrm{AB} 1$ rather than the previous methanol (highly toxic and flammable) or water based formulations. Further research by Sears et al. [35] has demonstrated that most protein stains behaved in a similar manner to AB1 and thus could be prepared using the WEAA solvent system.

An advantage of acid violet 19 (AV19) is the ability to lift the stained impression with a white gelatin lifter after enhancement. This in turn fluoresces under green light (473 - 548nm) when viewed with a $549 \mathrm{~nm}$ viewing filter and can enhance weak traces of protein containing material, even when present on dark surfaces [36-37]. Non-fluorescent stains have no enhancement effect on dark surfaces as the contrast is very poor. The performance of AY7 has been shown to improve with lighter deposits of blood and enhancement is viewed as fluorescent green-yellow by excitation with blue-green 385-509 $\mathrm{nm}$ light and viewed with a $510 \mathrm{~nm}$ Schott filter [38-39]. Nonetheless, it has been reported that AY7 is not suitable for porous surfaces since the dye cannot be washed off during the de-staining procedure [39].

To date no studies have been reported which comprehensively compare the range of available protein stains on the enhancement of repetitive marks in blood prepared under the exact same conditions and across a variety of fabric types. This study examines the effectiveness of 11 protein staining techniques to enhance repetitive marks made in blood on nine different fabric types. The fabrics investigated included natural and synthetic materials of a range of colour and porosity. The study also evaluates the effects that the preparation of the staining reagents and ageing of the marks has on the resultant enhancement. 


\section{MATERIALS AND METHODS}

\section{Protein Stain Formulation}

A full list of protein stains and fabrics utilised in the study are presented in tables 1 and 2 . Protein stains were prepared using the water/ethanol/acetic acid (WEAA) formulation [30, 35].

Table 1 - List of protein stains

\begin{tabular}{|c|c|c|c|c|}
\hline \multicolumn{5}{|c|}{ Protein Specific Stains } \\
\hline Name & $\begin{array}{l}\text { Alternative } \\
\text { Name }\end{array}$ & $\begin{array}{l}\text { Colour } \\
\text { Index }\end{array}$ & Supplier & Fluorescent \\
\hline $\begin{array}{l}\text { Acid Black } 1 \\
(\mathrm{AB} 1)\end{array}$ & Amido Black 10B & 20470 & BVDA & No \\
\hline $\begin{array}{l}\text { Acid Violet } 17 \\
\text { (AV17) }\end{array}$ & $\begin{array}{c}\text { Coomassie Violet R- } \\
200\end{array}$ & 42650 & BVDA & No \\
\hline $\begin{array}{c}\text { Acid Yellow } 7 \\
\text { (AY7) }\end{array}$ & $\begin{array}{c}\text { Brilliant } \\
\text { Sulphoflavine }\end{array}$ & 56205 & BVDA & Yes \\
\hline $\begin{array}{l}\text { Acid Violet } 19 \\
\text { (AV19) }\end{array}$ & Hungarian Red & 42685 & Acros & Yes \\
\hline $\begin{array}{c}\text { Acid Yellow } 23 \\
\text { (AY23) }\end{array}$ & Tartrazine & 19140 & Sigma-Aldrich & No \\
\hline $\begin{array}{l}\text { Acid Blue } 1 \\
\text { (ABlu1) }\end{array}$ & Patent Blue VF & 42045 & Acros & No \\
\hline $\begin{array}{l}\text { Acid Blue } 83 \\
\quad(A B 83)\end{array}$ & $\begin{array}{c}\text { Coomassie Brilliant } \\
\text { Blue R }\end{array}$ & 42660 & BVDA & No \\
\hline $\begin{array}{l}\text { Acid Red } 71 \\
\quad(\text { AR71) }\end{array}$ & Crocein Scarlet 7B & 27165 & BVDA & No \\
\hline $\begin{array}{l}\text { Acid Green } 50 \\
\text { (AG50) }\end{array}$ & Lissamine Green B & 44090 & Acros & No \\
\hline $\begin{array}{l}\text { Acid Red } \\
\text { 52(AR52) }\end{array}$ & Sulforhodamine B & 45100 & TCI Europe & Yes \\
\hline $\begin{array}{c}\text { Solvent Green } 7 \\
\text { (SG7) }\end{array}$ & Pyranine & 59040 & TCI Europe & Yes \\
\hline
\end{tabular}


Table 2 - List of fabrics

\begin{tabular}{|c|c|}
\hline Fabric & Supplier \\
\hline White Cotton & WBL Whaleys Bradford Ltd. \\
\hline Black Cotton & WBL Whaleys Bradford Ltd. \\
\hline Patterned Cotton & WBL Whaleys Bradford Ltd. \\
\hline White Polyester & WBL Whaleys Bradford Ltd. \\
\hline Black Polyester & WBL Whaleys Bradford Ltd. \\
\hline White Nylon/Lycra & WBL Whaleys Bradford Ltd. \\
\hline Black Nylon/Lycra & WBL Whaleys Bradford Ltd. \\
\hline Denim & Mandors, Glasgow, UK \\
\hline Bovine Leather & The Clyde Leather Co., Glasgow, UK \\
\hline
\end{tabular}

\section{Fixing solution:}

$23 \mathrm{~g}$ of 5-sulfosalicylic acid dihydrate (Acros) was dissolved and stirred in 1L of distilled water. This was used to fix the bloody impressions by immersion for a minimum period of 5 minutes.

\section{Staining solution:}

$1 \mathrm{~g}$ of the appropriate protein stain was stirred for at least 30 minutes in a solution of $50 \mathrm{~mL}$ of acetic acid, $250 \mathrm{~mL}$ of ethanol and $700 \mathrm{~mL}$ of distilled water. This was used to stain the blood impressions under test by immersion for a minimum period of 5 minutes. All of the formulations had a shelf-life of at least 12 months if refrigerated. AB83 and AR71 were removed from the list of techniques in the early stages of the experimental work as their enhancement potential and colour was deemed to be similar or of lesser quality to AV17 and AV19 respectively.

\section{De-staining solution:}

The final de-staining methodology used in this study was to first rinse under running tap water for several minutes to remove the excess dye (as suggested by Bodziak [40]) followed by immersion in a de-staining solution of $50 \mathrm{~mL}$ of acetic acid, $250 \mathrm{~mL}$ of ethanol and 700 $\mathrm{mL}$ of ethanol. 


\section{Fluorescence observations}

The appropriate excitation wavelengths and viewing filters which were utilised for observation of the fluorescent protein stains are presented in table 3.

Table 3 - Excitation wavelength and viewing filters for fluorescent protein stains

\begin{tabular}{|c|c|c|c|c|}
\hline $\begin{array}{c}\text { Chemical } \\
\text { Name }\end{array}$ & $\begin{array}{c}\text { Excitation } \\
\text { Wavelength/nm }\end{array}$ & $\begin{array}{c}\text { Excitation } \\
\text { Filters }\end{array}$ & $\begin{array}{c}\text { Viewing } \\
\text { Filter/nm }\end{array}$ & $\begin{array}{c}\text { Viewing } \\
\text { Filter }\end{array}$ \\
\hline AY7 & $385-509$ & Blue & 510 & Yellow/Orange \\
\hline AV19 & $473-548$ & Green & 549 & Orange \\
\hline SG7 & $350-469$ & Violet/Blue & 476 & Yellow \\
\hline AR52 & $503-591$ & Green/Yellow & 593 & Red \\
\hline
\end{tabular}

\section{Deposition of the footwear impressions and preparation of the test marks}

The objective of this work was the comparison of the ability of various protein stains to enhance the footwear mark, rather than mimic operational conditions normally encountered. Only when repeatability of the quality of the footwear impression produced is controlled (such that there was no variation from mark to mark) could a direct comparison of the various stains be reliably achieved.

Variables introduced during the preparation of test footwear impressions include the pressure of the footwear sole on the receiving surface as the footwear impression is made [41]. It can be argued that robust comparisons of footwear enhancement techniques can only be made if the test footwear impressions have been prepared in the same manner where these factors have been controlled in each case.

In this work the pressure applied to the receiving surface by the blood contaminated footwear was precisely controlled using a rig developed and calibrated for that purpose and presented in figure 3. The device was calibrated to deliver a force comparable with the average force used in a stamping action as determined through trials conducted with live volunteers (3500 Newtons) in a repeatable manner. 


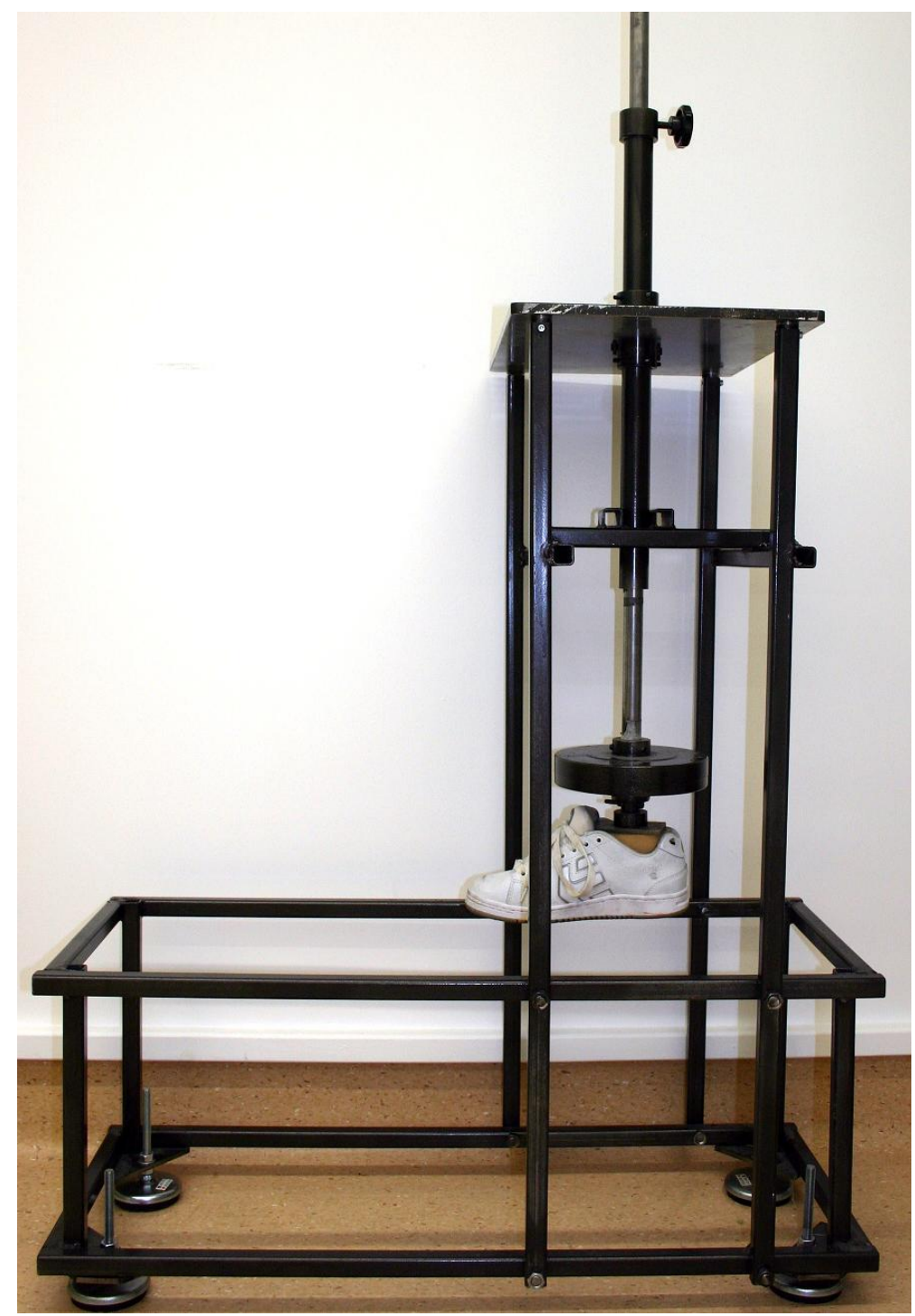

Figure 3 - Semi-Automated Stamping Device

Other influencing factors on the quality of the mark include the amount and composition of blood on the footwear sole prior to being transferred to the receiving surface and the actual amount of contaminant transferred to the substrate. The application of blood to the footwear sole and the subsequent transfer of blood to a substrate are challenging to control during experimental trials. Stepping into a pool of blood followed by stepping onto the fabric resulted in a heavy blood-stained and overloaded footwear impression. The following method however yielded reasonably weak and reproducible bloody impressions from mark to mark. A tray measuring $0.33 \times 0.23 \times 0.06 \mathrm{~m}$ was lined with two Kimberley ${ }^{\circledR}$ blue double ply tissues covering the whole base. $50 \mathrm{~mL}$ of swine blood was poured over the tissues. The tray was then pushed against the sole of the footwear attached to the rig in a walking motion. The same motion was repeated twice on clean tissues to remove excess blood before releasing the foot onto the fabric. 
Six individual repeat footwear marks were prepared as described for all tests undertaken. All impressions were allowed to age for 7 days before enhancement with the various protein stains. Photography of all impressions was performed immediately after the impression was prepared, after 7 days, after chemical treatment and during fluorescence examination if required.

\section{Comparison of commercial protein stains and freshly prepared solutions}

Most protein stains are commercially available as pre-mixed or 'ready-made' solutions. A comparison was performed between commercially available solutions and solutions prepared from raw chemicals on marks prepared on white cotton only. The protein stains included in this study were acid black 1 (AB1), acid violet 17 (AV17), acid violet 19 (AV19), crocein scarlet (AR71) and coomassie blue (AB83). Pre-mixed solutions were purchased from BVDA (Netherlands) and fresh solutions were prepared according to the HOSDB formulations [35, 38]. BVDA solutions of fix and protein stains were sprayed on the bloody impression whereas freshly prepared solutions were applied by immersion.

\section{Effect of ageing}

Bloody footwear impressions can deteriorate over time, even in indoor or sheltered environments [42]. A mini-study was devised to compare the enhancement of footwear impressions in blood with AB1, AV17 and AV19 on white cotton that had been aged for 1, 7, 10 and 28 days.

\section{Diminishing Series}

A diminishing series was prepared by stepping on a blood soaked tissue and then using the test rig to produce ten bloody impressions for each fabric with the first one being the most blood-stained. The impressions were left to air dry for one week before treatment. 


\section{RESULTS AND DISCUSSION}

\section{Comparison of different protein stains}

All protein stains behaved in a similar manner with the fluorescent stains having the added advantage of fluorescence..

\section{Fabric type}

Black polyester exhibited some additional advantages when enhanced with protein stains. Under normal white lighting, the protein stain enhancement was very weak. However, with oblique lighting the footwear impression could be visualised quite well and is illustrated in figure 4. The marks on black polyester were also visualised during fixation (figure 5) when the black polyester was immersed in the fixing solution of $2 \% 5$-sulfosalicylic acid. This was not observed for the other black fabrics (nylon/lycra or cotton).

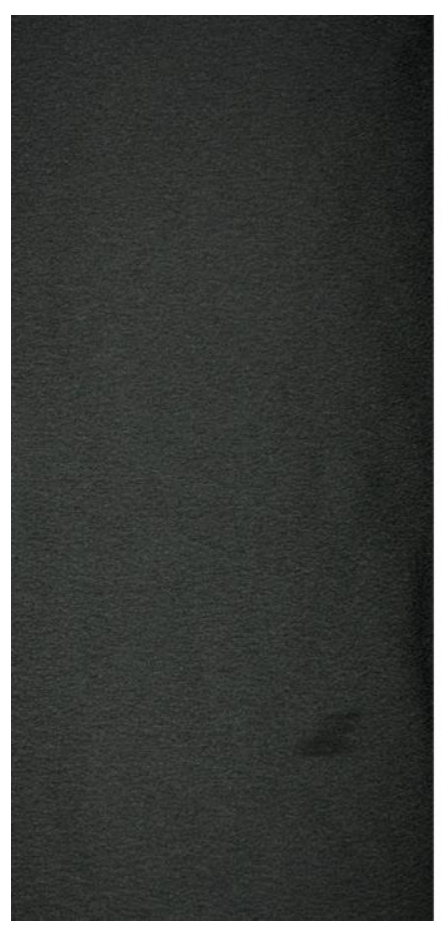

(a)

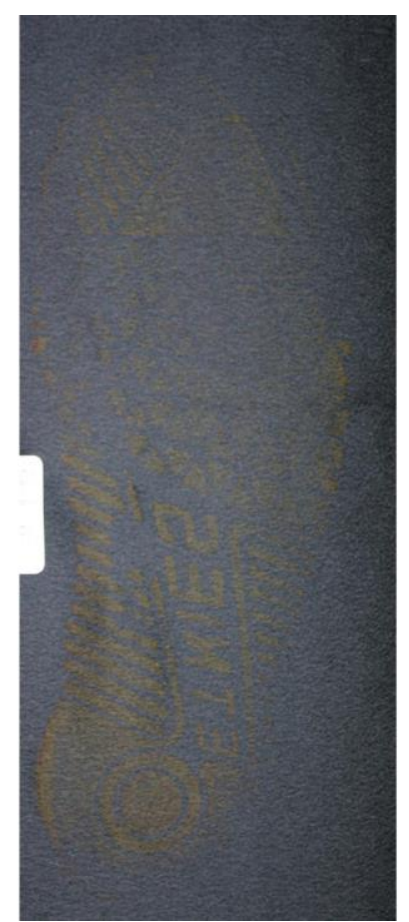

(b)

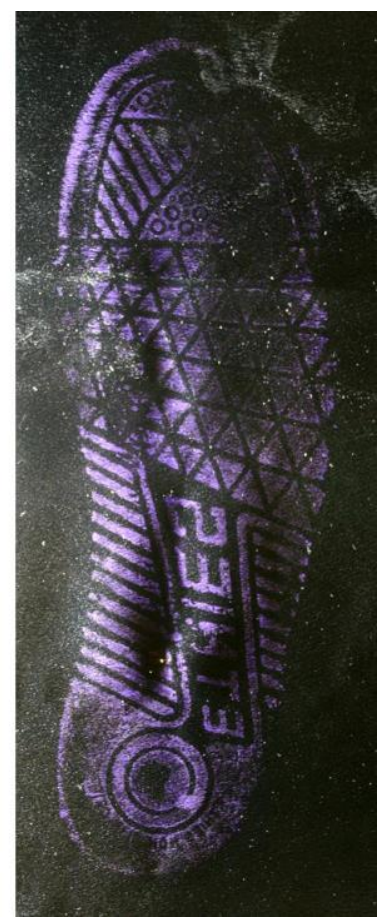

(c)

Figure 4- Enhancement of a footwaer impression in blood on black polyester with AV17: (a) blood impression before enhancement; (b) AV17 enhancement under white light; (c) visualisation of (b) using oblique lighting 


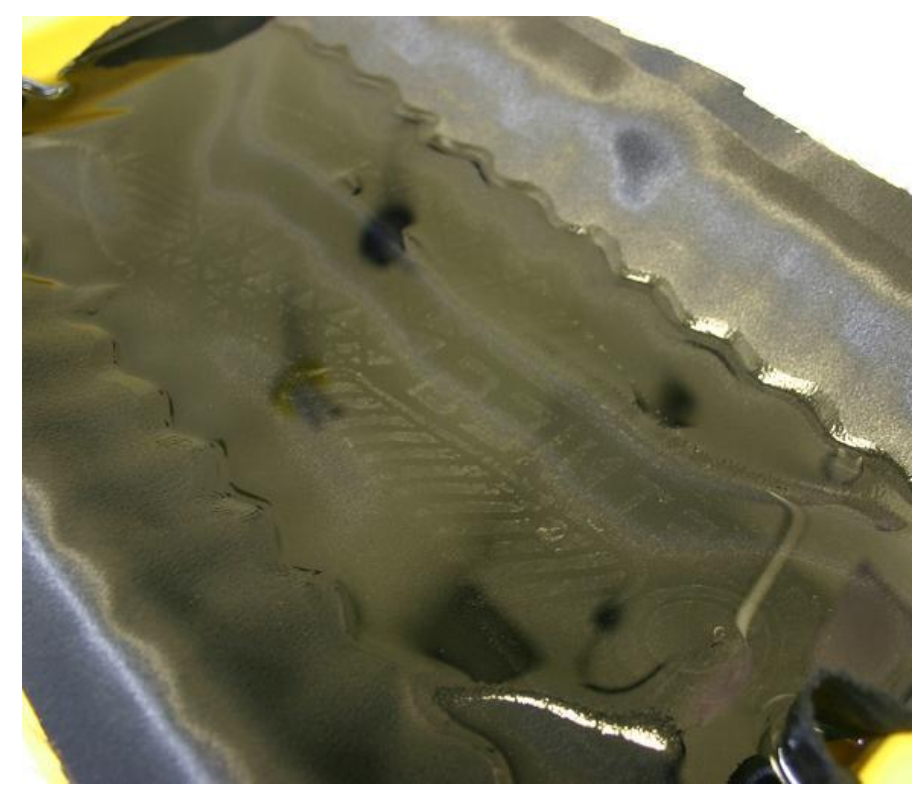

Figure 5 - Visualisation of a footwear impression in blood on black polyester during fixation

Footwear marks produced on leather left a faint indentation of the footwear sole in the fabric material and the blood footwear impression was clearly visible when compared with similar marks on the other fabrics as illustrated in figure 6. Enhancement of the blood impressions on leather with all of the protein stains appeared to obliterate the impression and the stain did not wash off during the de-staining procedure.

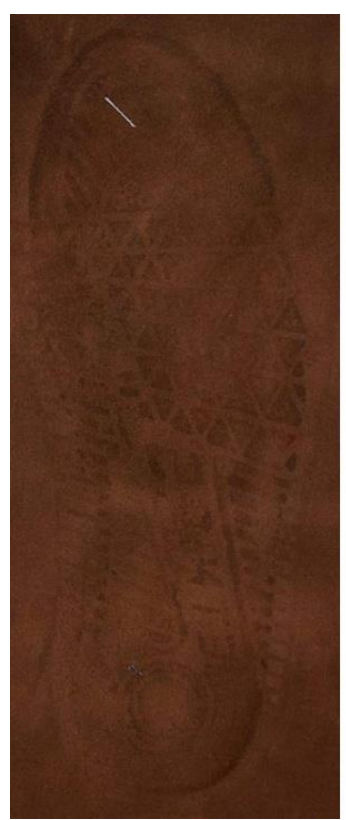

(a)

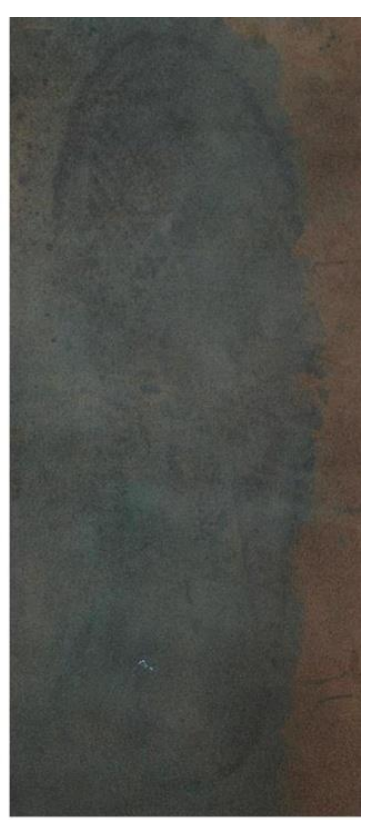

(b)

Figure 6 - Enhancement of a footwear impression in blood on leather with AB1: (a) before enhancement; (b) after enhancement 


\section{De-staining}

The protein stains washed off very well during the de-staining procedure from synthetic fabrics when compared to the natural fabrics (figure 7). Background staining was more prominent on cotton and this can be explained by the fact that synthetic fibres, such as polyester, are hydrophobic and thus will repel acidic dyes [43]. The protein stain was almost completely washed off from white polyester after de-staining.
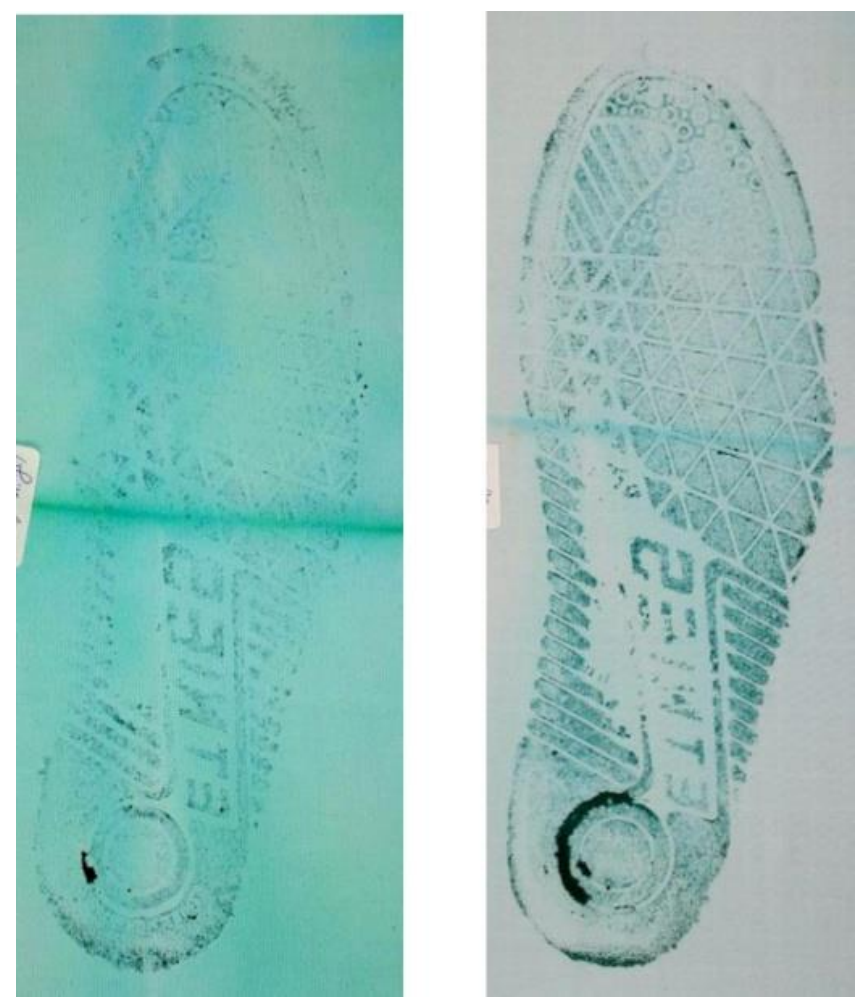

Figure 7 - Enhancement of a footwear impression in blood with ABlu1: (a) white cotton; (b) white nylon/lycra

\section{Fluorescence}

In general fluorescence did not further enhance impressions on the light coloured fabrics and in some circumstances the bright fluorescence on white fabrics, obscured the impression potentially due to optical brighteners in white fabrics [44-45]. Fluorescent AY7 provided excellent results on dark coloured fabrics when illuminated with blue light. This study showed vivid visual yellow enhancement on bloody impressions on light coloured fabrics in contrast to previous research by the HOSDB [39] that had concluded that AY7 did not impart any visual colour unless dyeing times were greatly increased. The HOSDB [39] study 
had also highlighted the fact that AY7 was unsuitable for porous surfaces as it was impossible to wash off the dye from the background. However, the opposite was found to be true in this study where most of the dye washed off easily. AY7 fluorescence enhancement of bloody impressions on black fabrics provided excellent results (figure 8) although the fluorescence on denim and leather was very weak. Fluorescence using a Crime-Lite ${ }^{\mathrm{TM}}$ and Quasar 40 showed similar results. The fluorescence observed from enhancement with protein stains AV19, AR52 and SG7 behaved similar to but not as vivid as AY7, and visual/background staining with SG7 was minimal or non-existent. The use of SG7 and AR52 has not previously been reported in the literature for the enhancement of bloody impressions. Figure 9 shows the fluorescence enhancement of bloody footwear impressions on black cotton with AY7, AV19, AR52 and SG7

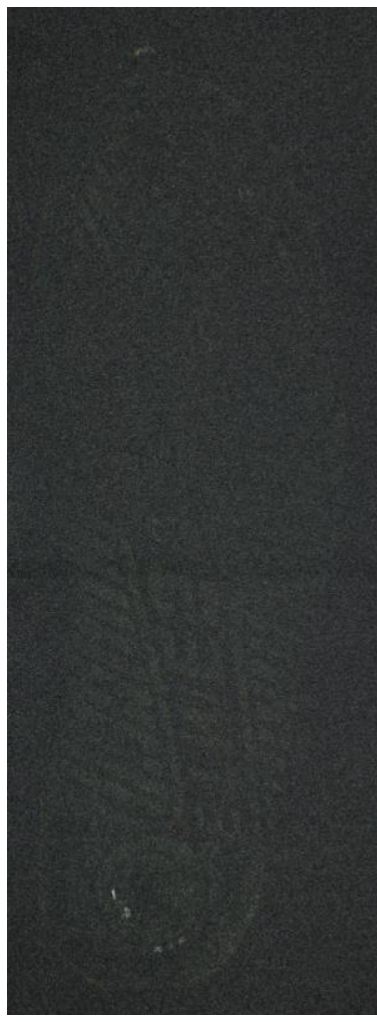

(a)

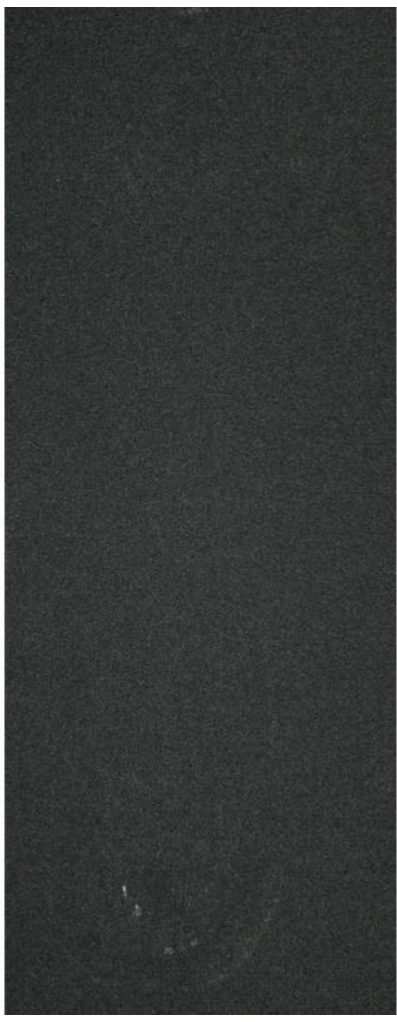

(b)

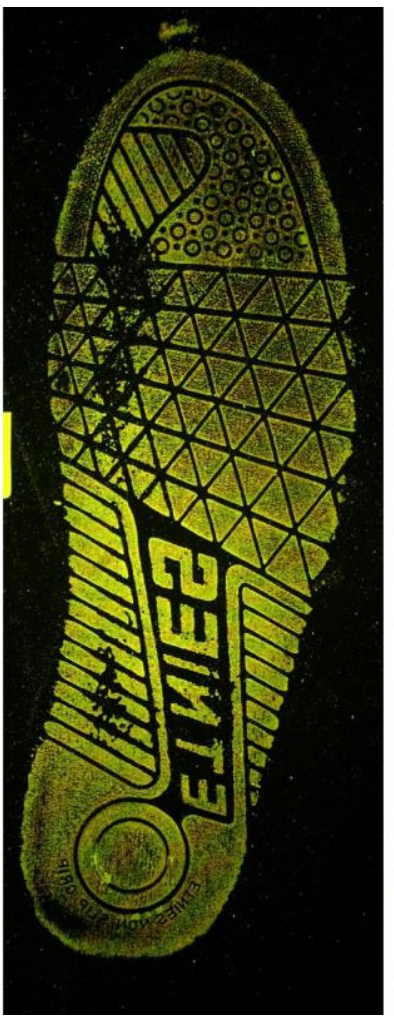

(c)

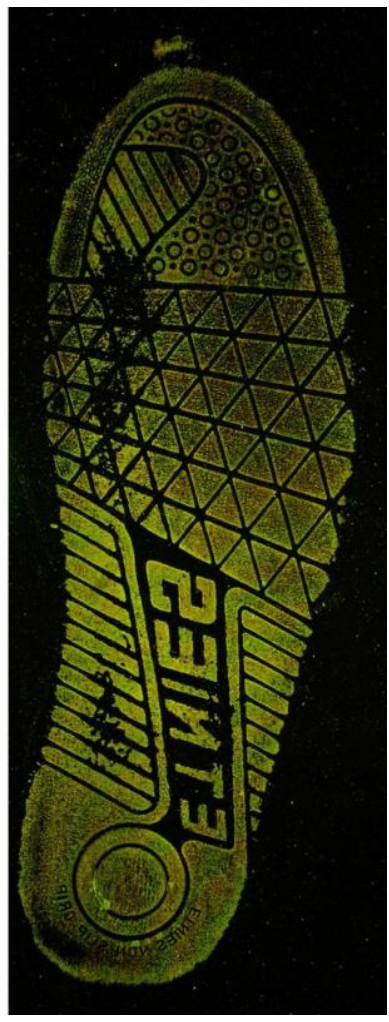

(d)

Figure 8 - Enhancement of a footwear impression in blood on black nylon/lycra: (a) blood impression before enhancement; (b) enhancement with AY7 under white light; (c) AY7 fluorescence using Blue Crime-Lite ${ }^{\mathrm{TM}}$; (d) AY7 fluorescence using Quasar 40 385- 


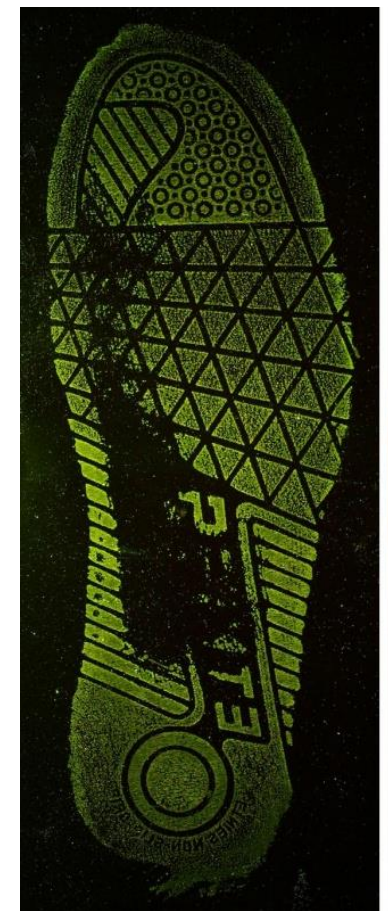

(a)

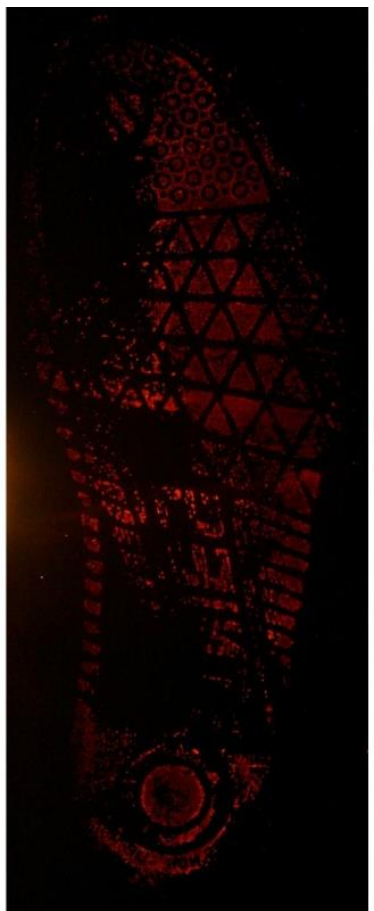

(b)

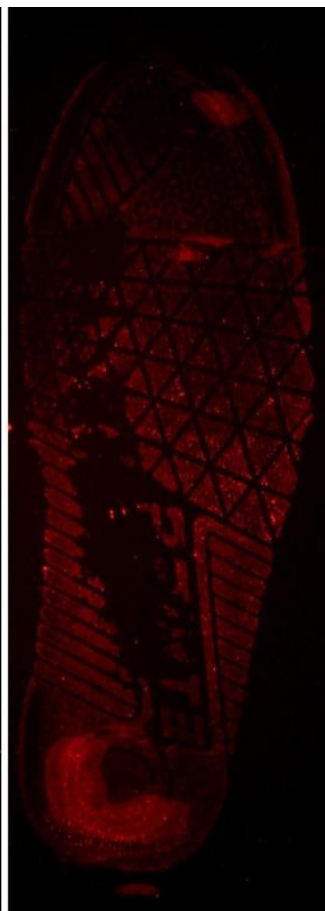

(c)

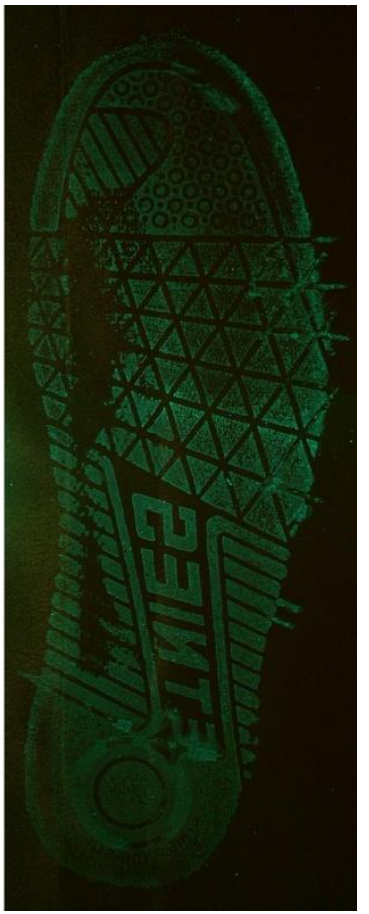

(d)

Figure 9 - Enhancement of a footwear impression in blood on black cotton with: (a) AY7; (b) AV19; (c) AR52 and (d) SG7

It was not initially clear why the fluorescence on denim and leather was weak compared to the black fabrics. The enhancement with AY7 on denim was repeated using other coloured denim fabrics (bright blue, dark blue, faint blue, red, black and grey). AY7 fluorescence enhancement for all these fabrics was still weak suggesting the use of indigo and vat dyes, commonly used in dyeing denim [46-50], might interfere with the AY7 fluorescence. Figure 10 shows the AY7 fluorescence enhancement of blood impressions on differently coloured denim. Recent research has suggested that a lifted blood impression that had been treated with AV19 and lifted with a white gelatin lifter fluoresced under green light [33, 37]. Furthermore, a 1:100 dilution of the AV19 solution could provide direct fluorescence without lifting. The gelatin lifter was left on the blood impression for at least 15-30 minutes before removing [36]. Longer periods of up to two hours were tested but no further improvement on fluorescence was observed. In this study, preliminary studies showed that no enhancement was achieved by lifting with a white gelatin lifter after staining with AV19 or other protein stains on any type of fabric. Diluting the AV19 stain solution by a factor of 100 however produced a weak fluorescence by exciting with a green light $(473-548 \mathrm{~nm})$ and viewed with a $549 \mathrm{~nm}$ Schott filter (figure 11). 


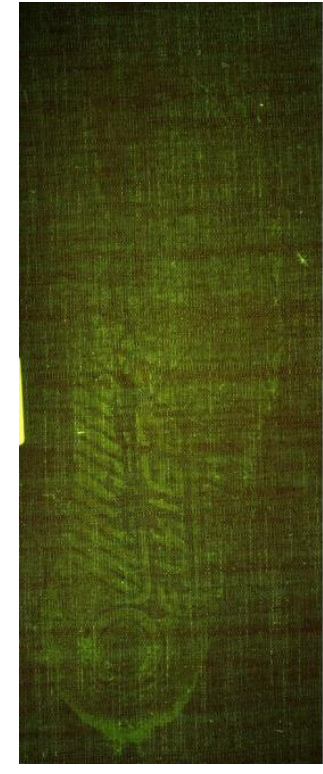

(a)

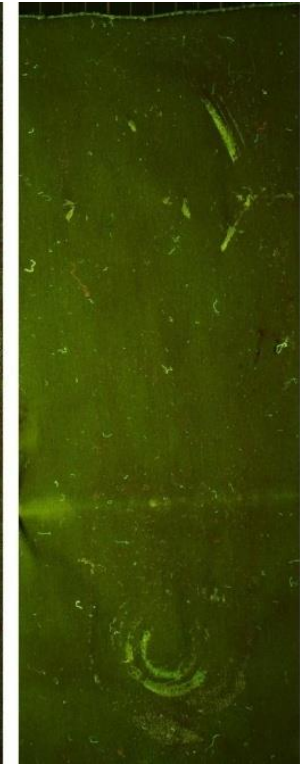

(b)

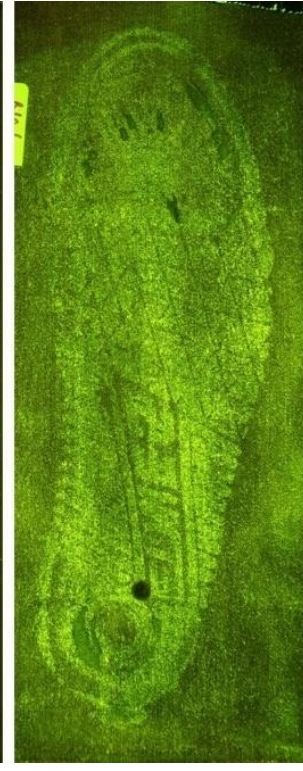

(c)

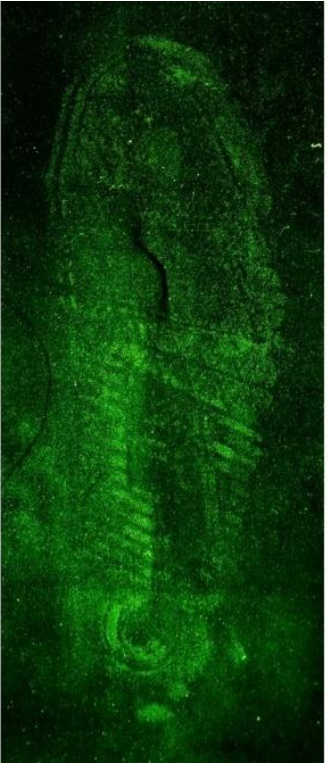

(d)

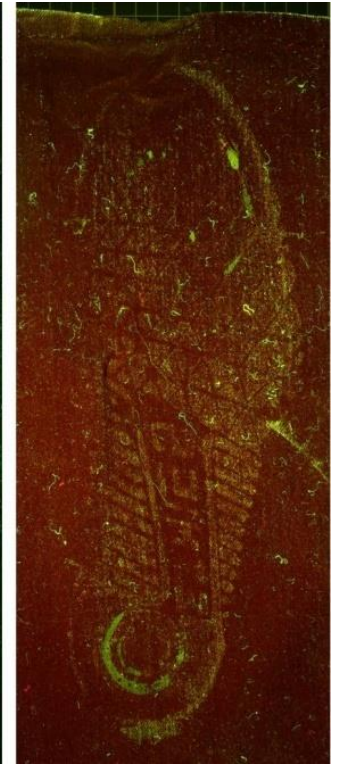

(e)

Figure 10 - AY7 fluorescence enhancement of footwear impression in blood on coloured denim: (a) blue; (b) bright blue; (c) grey; (d) black; (e) red

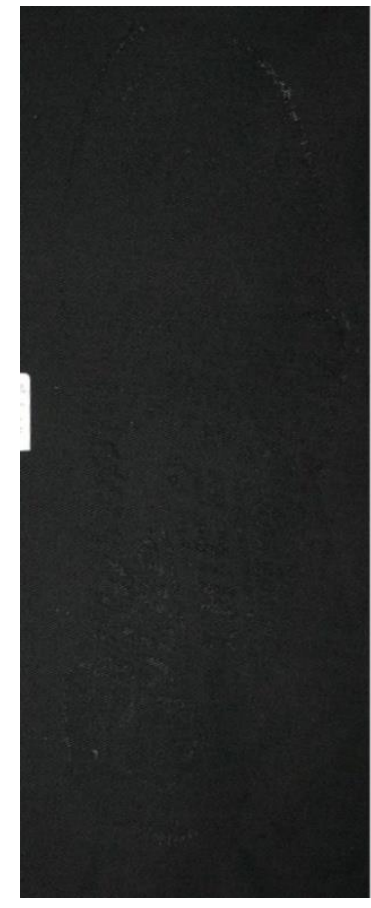

(a)

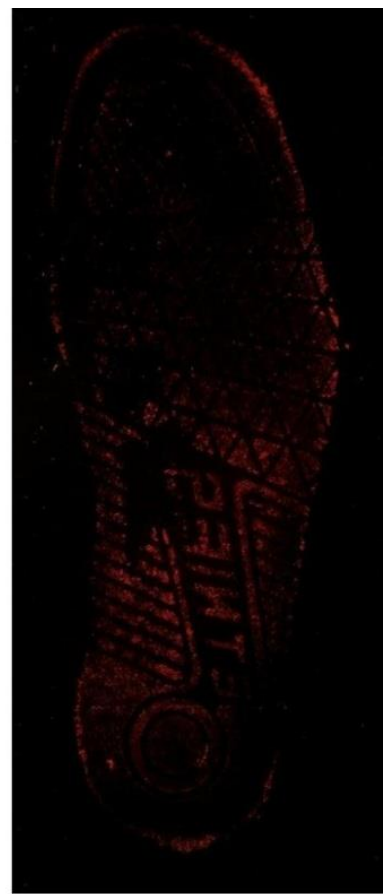

(b)

Figure 11 - Enhancement of a footwear impression in blood on black cotton with AV19: (a) under white light; (b) under green light (473-548 nm) 


\section{Comparing commercial protein stains and freshly prepared solutions}

Both the commercially prepared and laboratory prepared solutions successfully enhanced all of the blood impressions prepared on white cotton with no discernable differences. The premixed solutions however had no indication of their shelf-life or an expiry date. A blood footwear impression before and after enhancement with AV17 from BVDA and laboratory prepared AV17 is presented in figure 12.

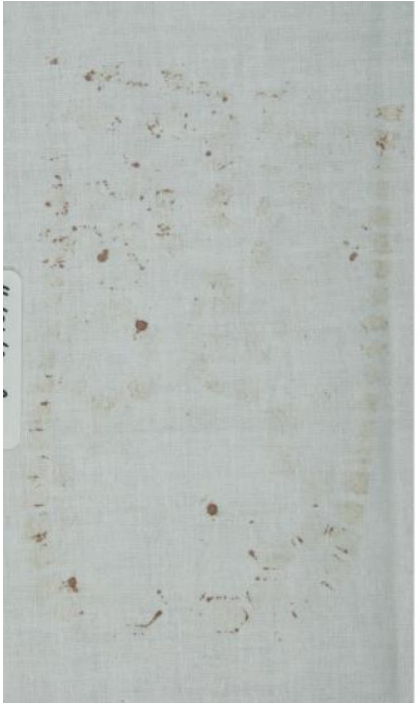

(a)

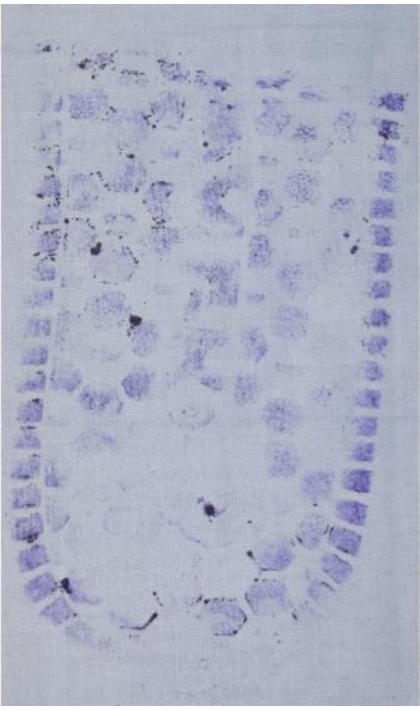

(b)

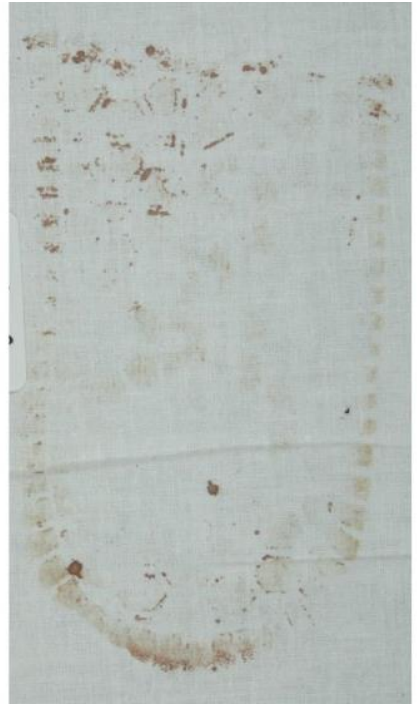

(c)

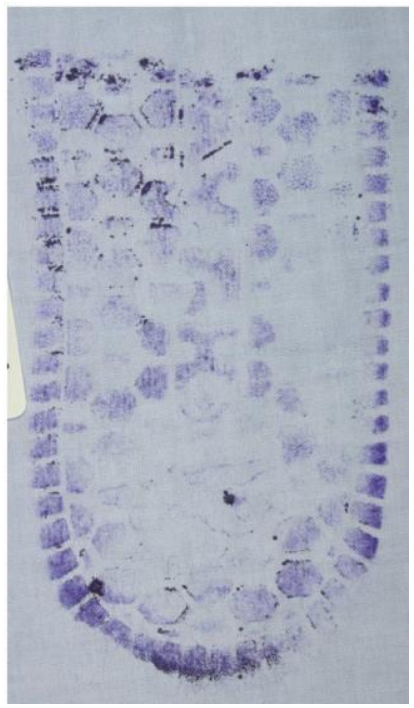

(d)

Figure 12 - Enhancement of a footwear impression in blood on white cotton:

(a) blood impression; (b) enhancement of (a) with BVDA AV17; (c) blood impression; (d) enhancement of (c) with fresh AV17 solution

\section{Effect of Ageing}

In general, the enhanced blood impressions appeared visually similar after the different ageing periods had elapsed and no obvious changes were observed.

\section{Diminishing Series}

The diminishing series work was carried out using acid yellow 7 only as the best responding reagent for the blood marks. AY7 enhancement for the diminishing series of impressions made in blood was not possible beyond the third impression. Fluorescence improved the contrast on black coloured fabrics and slightly weakened the contrast on light coloured 
fabrics. An interesting observation was that the first impression on denim and leather fluoresced strongly, compared to the second impression and the rest of the series. This suggests that fluorescence was weak on denim and leather in previous studies because of the absence of blood in the impression rather than an effect of the surface and that previous results were obtained as a result of the poor ability of these fabrics to retain blood.

This weakly enhanced diminishing series can be explained by the ability of fabrics to retain the blood. There is in fact a relationship between the type of fabric and the retention of bloodstains; Cox [51] observed that blood was absent from synthetic fabrics (acetate, polyester and nylon) but present in all cotton fabrics after washing in a washing machine. The results of the diminishing series are illustrated in figure 13.
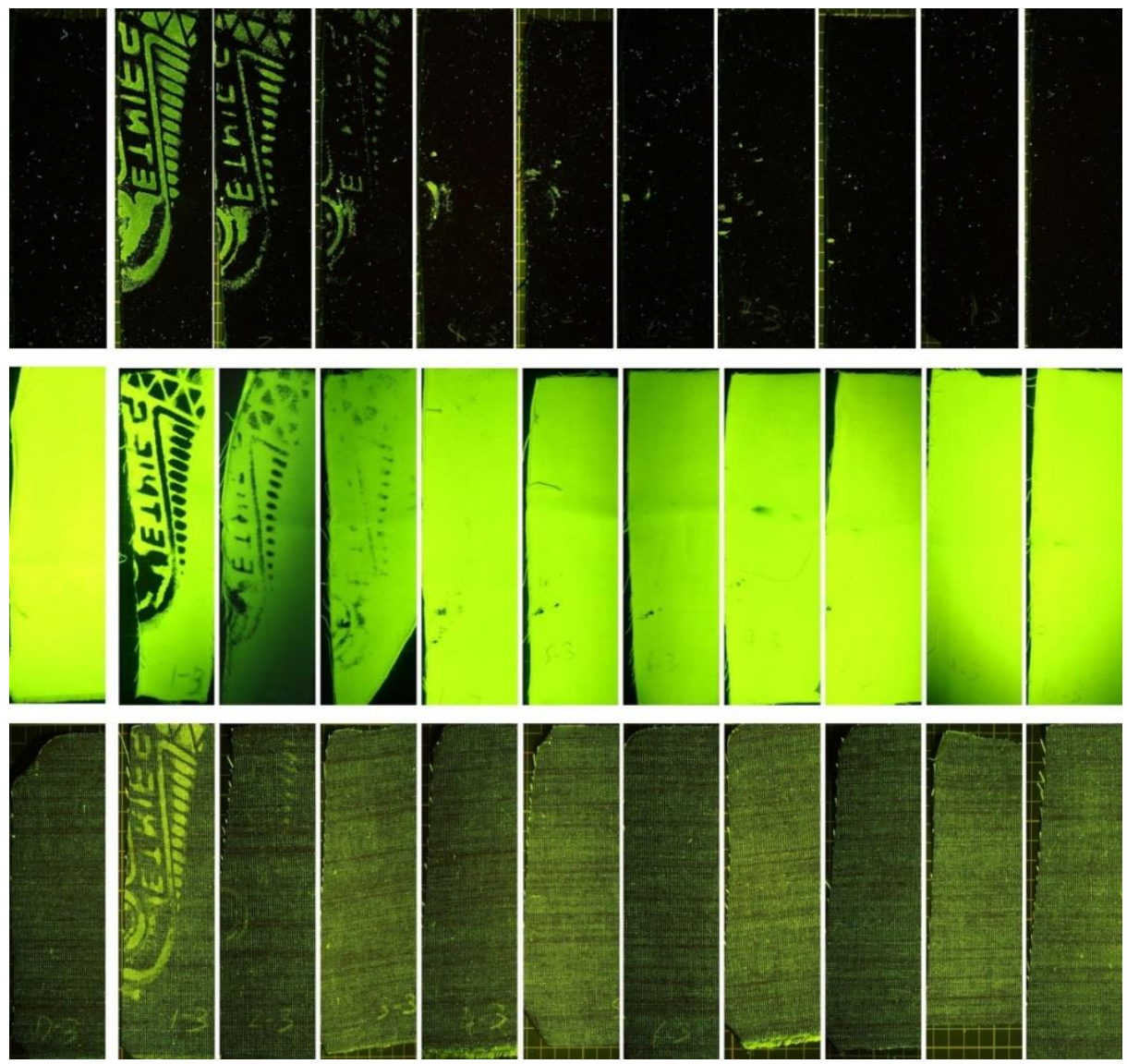

Figure 13 - AY7 fluorescence enhancement for a diminishing series in blood for: black cotton, white cotton and denim 


\section{CONCLUSION}

The results clearly showed that AY7 is the most suitable enhancement technique for footwear impressions made in blood and deposited on to dark fabrics. Limited fluorescence was observed for similar marks on denim and leather. Similar but weaker results were obtained with other fluorescent protein stains. Other protein stains performed equally well on light coloured fabrics and the authors believe that the HOSDB recommendations of protein stains $\mathrm{AB} 1, \mathrm{AB} 17$ and AY7 is appropriate for such substrates. Their use is not strictly limited to non-porous substrates, however, it is highly recommended to test an area of the substrate beforehand away from the blood impression. Furthermore, observations under different lighting conditions and fluorescence should be included in routine analysis as a great improvement in the contrast of the enhanced can be obtained. 


\section{ACKNOWLEDGEMENTS}

The authors would like to thank HOSDB, EPSRC and the University of Strathclyde for their continued financial support. This work is also partially funded by the Malta Government Scholarship Scheme. 


\section{REFERENCES}

1. Zauner, D.R., Friction Ridge Impression in Blood on Blue Denim, Journal of Forensic Identification, 1998, 48(6): p. 689-691.

2. Frégeau, C.J., Germain, O., and Fourney, R.M., Fingerprint Enhancement Revisited and the Effects of Blood Enhancement Chemicals on Subsequent Profiler Plus ${ }^{\mathrm{TM}}$ Fluorescent Short Tandem Repeat DNA Analysis of Fresh and Aged Bloody Fingerprints, Journal of Forensic Science, 2000, 45(2): p. 354-380.

3. Ganson, A., Latent Fingerprints on Paper and Fabrics, Identification News, 1973, 23(2): p. 35.

4. Spedding, D.J., Detection of Latent Fingerprints with ${ }^{35} \mathrm{SO}_{2}$, Nature, 1971, 229: p. 123.

5. Phillips, C.E., Cole, D.O., and Jones, G.W., Physical Developer: A Practical and Productive Latent Developer, Journal of Forensic Identification, 1990, 40(3): p. 135-147.

6. Ramotowski, R.S., Importance of an Acid Prewash Prior to the Use of Physical Developer, Journal of Forensic Identification, 1996, 46(6): p. 673-677.

7. Ramotowski, R.S., A Comparison of Different Physical Developer Systems and Acid Pretreatments and Their Effects on Developing Latent Prints, Journal of Forensic Identification, 2000, 50(4): p. 363-384.

8. Cantu, A.A., Silver Physical Developers for the Visualisation of Latent Prints on Paper, Forensic Science Review, 2001, 13: p. 29-64.

9. Burow, D., An Improved Silver Physical Developer, Journal of Forensic Identification, 2003, 53(3): p. 304-314.

10. Burow, D., Seifert, D., and Cantu, A.A., Modifications to the Silver Physical Developer, Journal of Forensic Science, 2003, 48(5).

11. Wilson, J.D., Cantu, A.A., Antonopoulos, G., and Surrency, M.J., Examination of the Steps Leading up to the Physical Developer Process for Developing Fingerprints, Journal of Forensic Science, 2007, 52(2): p. 320-329.

12. Beaudoin, A., New Technique for Revealing Latent Fingerprints on Wet, Porous Surfaces: Oil Red O, Journal of Forensic Identification, 2004, 54(4): p. 413-421.

13. Rawji, A. and Beaudoin, A., Oil Red O Versus Physical Developer on Wet Papers: A Comparative Study, Journal of Forensic Identification, 2006, 56(1): p. 33-54.

14. Cantu, A.A., Burow, D., and Wilson, J.D., On Some Properties of the Oil Red O Fingerprint Visualization Reagent, in 6th International Fingerprint Research Group (IFRG), 2007. Cranberra, Australia, 25 - 30 March.

15. Guigui, K. and Beaudoin, A., The use of Oil Red O in Sequence with Other Methods of Fingerprinting Methods, Journal of Forensic Identification, 2007, 57(4): p. 550-581.

16. Mack, N. and Wilson, G., Evaluation of Oil Red O. 2007: Internal Report, Forensic Science Service (FSS) Ltd, UK Government.

17. Salama, J., Aumeer-Donovan, S., Lennard, C.J., and Roux, C., Evaluation of Oil Red O as a Fingermark Detection Reagent for use as a Replacement for or in Sequence with Physical Developer, in 6th International Fingerprint Research Group (IFRG), 2007. Canberra, Australia, 25 - 30 March.

18. Wood, M.A. and James, T., ORO. The Physical Developer replacement?, Science \& Justice, 2009, 49(4): p. 272-276.

19. James, J. and Tas, J., Histochemical Protein Staining Methods. 1984, Oxford: Oxford University Press.

20. Horobin, R.W., Histochemistry - An Explanatory Outline of Histochemistry and Biophysical Staining. 1982, London: Butterworths.

21. Hopwood, D., Fixatives and Fixation: A Review, Histochemical Journal, 1969, 1: p. 323360 .

22. Hussain, J.I. and Pounds, C.A., The Enhancement of Marks in Blood, Part I: 5-sulfosalicylic acid: A Convenient and Effective Fixative for Marks Made in Blood, Central Research Establishment Report, 1988, No. 649(February 1988). 
23. Mondino, A., Bongiovanni, G., Fumero, S., and Rossi, L., An improved method of plasma deproteination with sulphosalicylic acid for determining amino acids and related compounds, Journal of Chromatography A, 1972, 74(2): p. 255-263.

24. Horobin, R.W. and Kiernan, J.A., Conn's biological stains : a handbook of dyes, stains and fluorochromes for use in biology and medicine 10th ed. 2002: Oxford.

25. Green, F.J., The Sigma-Aldrich Handbook of Stains, Dyes and Indicators. 1990: Aldrich Chemical Company, Milwaukee.

26. Kiernan, J.A., Histological and Histochemical Methods: Theory and Practice. 1989, Oxford: England: Pergamon Press.

27. The Society of Dyers and Colourists, Colour Index International. 1996.

28. Wilson, C.M., An Update on Protein Stains: Amido Black, Coomassie Blue G, and Coomassie Blue R, Biotechnic and Histochemistry, 1992, 67(4): p. 224 - 234.

29. Ball, M.T., Hay, J., Masrouji, H.M., and Sugden, J.K., Photochemical degradation of C.I. acid black 1, Dyes and Pigments, 1992, 19(1): p. 51-57.

30. Bowman, V., Ed. Manual of Fingerprint Development Techniques, 2nd ed. 2005, Home Office Scientific Development Branch: Sandridge, UK.

31. Bowman, V., Ed. Fingerprint Development Handbook, 2nd ed. 2005, Home Office Scientific Development Branch: Sandridge, UK.

32. Marchant, B. and Tague, C., Developing Fingerprints in Blood: A Comparison of Several Chemical Techniques, Journal of Forensic Identification, 2007, 57(1): p. 76-93.

33. Theeuwen, A.B.E., van Barneveld, S., Drok, J.W., Keereweer, I., Limborgh, J.C.M., Naber, W.M., and Velders, T., Enhancement of Footwear Impressions In Blood, Forensic Science International, 1998, 95(2): p. 133-151.

34. Sears, V.G. and Prizeman, T.M., Enhancement of Fingerprints in Blood - Part 1: The Optimisation of Amido Black, Journal of Forensic Identification, 2000, 50(5): p. 470-480.

35. Sears, V.G., Butcher, C.P.G., and Prizeman, T.M., Enhancement of Fingerprints in Blood Part 2: Protein Dyes, Journal of Forensic Identification, 2001, 51(1): p. 28-38.

36. James, S.H., Kish, P.E., and Sutton, T.P., Principles of Bloodstain Pattern Analysis: Theory and Practice, 3rd Edition ed. 2005, FL: CRC Taylor and Francis Group LLC.

37. Velders, M.J.M., Fluorescing Traces in Blood on White Gelatin Lifters with Hungarian Red, in 81st Educational Conference of the International Association of Identification, 1996. Greensboro, NC.

38. Home Office Scientific Development Branch, Manual of Fingerprint Development Techniques, 2nd ed, ed. Bowman, V. 2005: HOSDB.

39. Sears, V.G., Butcher, C.P.G., and Fitzgerald, L.A., Enhancement of Fingerprints in Blood Part 3: Reactive Techniques, Acid Yellow 7, and Process Sequences, Journal of Forensic Identification, 2005, 55(6): p. 741-763.

40. Bodziak, W.J., Footwear Impression Evidence: Detection, Recovery and Examination, 2nd ed. 2000, London: CRC Boca Raton.

41. Paine, N., Use of Cyanoacrylate Fuming and Related Enhancement Techniques to Develop Shoe Impressions on Various Surfaces, Journal of Forensic Identification, 1998, 48(5): p. 585-601.

42. Morgan-Smith, R.K., Elliot, D.A., and Adam, H., Enhancement of Aged Shoeprints in Blood, Journal of Forensic Identification, 2009, 59(1): p. 45-50.

43. Horobin, R.W., Biological Stains. December 2009, Personal Communication: Glasgow.

44. Sarkar, A.K., Fluorescenet Whitening Agents. 1971, Herts, England: Merrow Publishing Co. Ltd.

45. LLoyd, J.B.F., Forensic Significance of Fluorescent Brighteners: Their Qualitative TLC Characterisation in Small Quantities of Fibre and Detergents., Journal of the Forensic Science Society, 1977, 17(2): p. 145-152.

46. Laing, D.K., Dudley, R.J., Hartshorne, A.W., Home, J.M., Rickard, R.A., and Bennett, D.C., The extraction and classification of dyes from cotton and viscose fibres, Forensic Science International, 1991, 50(1): p. 23-35. 
47. Suzuki, S., Suzuki, Y., Ohta, H., Sugita, R., and Marumo, Y., Microspectrophotometric discrimination of single fibres dyed by indigo and its derivatives using ultraviolet-visible transmittance spectra, Science \& Justice, 2001, 41(2): p. 107-111.

48. Grieve, M.C., Biermann, T.W., and Schaub, K., The use of indigo derivatives to dye denim material, Science \& Justice, 2006, 46(1): p. 15-24.

49. Biermann, T.W., Blocks of colour IV: The evidential value of blue and red cotton fibres, Science \& Justice, 2007, 47(2): p. 68-87.

50. Dockery, C.R., Stefan, A.R., Nieuwland, A., Roberson, S.N., Baguley, B.M., Hendrix, J.E., and Morgan, S.L., Automated extraction of direct, reactive, and vat dyes from cellulosic fibers for forensic analysis by capillary electrophoresis, Analytical and Bioanalytical Chemistry, 2009, 394(8): p. 2095-2103.

51. Cox, M., Effect of Fabric Washing on the Presumptive Identification of Bloodstains, Journal of Forensic Science, 1990, 35(6): p. 1335-1341. 